\title{
Why lithium studies for ALS treatment should not be halted prematurely
}

\author{
Galila Agam ${ }^{1 *}$ and Adrian Israelson ${ }^{2 *}$ \\ ${ }^{1}$ Department of Clinical Biochemistry and Pharmacology, Faculty of Health Sciences and Psychiatry Research Unit, Ben Gurion University of the Negev, Beer \\ Sheva, Israel \\ 2 Department of Physiology and Cell Biology, Faculty of Health Sciences, Ben Gurion University of the Negev, Beer Sheva, Israel \\ *Correspondence: galila@bgu.ac.il; adriani@bgu.ac.il
}

\section{Edited by:}

John A. Rudd, Chinese University of Hong-Kong, China

Reviewed by:

Stina Syvänen, Uppsala University, Sweden

Keywords: lithium, ALS, effective blood levels, riluzole, mouse strains

\section{A commentary on}

Make mouse studies work

by Perrin, S. (2014). Nature 507, 423-425. doi: $10.1038 / 507423 a$

Perrin's recent comment (Perrin, 2014) emphasizes that mouse studies must be sibling-matched, gender-balanced, and investigator-blinded. To substantiate his claim, Perrin provides examples from studies on lithium as a treatment for ALS, describing them as misleading. While we fully agree that there is a need for better designed preclinical studies and better characterization of disease models, Perrin's examples are problematic. First, Perrin's pharmacokinetic calculations of the dosing regimens predict plasma lithium levels of $0.3-1.68 \mathrm{meq} / \mathrm{L}$. However, given that the beneficial therapeutic window in bipolar-disorder is $0.6-1.5 \mathrm{meq}$ lithium $/ \mathrm{L}$, it is conceivable that only regimens resulting in blood levels $\geq 0.6 \mathrm{meq} / \mathrm{L}$ would lead to beneficial results. Second, instead of theoretical calculations lithium levels should be measured directly. We recently reported that lithium blood levels of ICR mice bred separately in the USA and Israel, but treated in the same facility with the same supplemented food, differed by 2.5 -fold (Sade et al., 2014). This difference may explain why, despite using the same regime, the Fornai et al. (2008) and Gill et al. (2009) studies produced opposite results. Third, daily intraperitoneal lithium injections rather than the less irritating food supplementation method might also contribute to unsuccessful outcomes.
In negative ALS clinical trials (UKMND-LiCALS Study Group et al., 2013) plasma lithium levels were $0.4-0.8 \mathrm{meq} / \mathrm{L}$, barely at the lower therapeutic range for psychiatric disorders and significantly lower than the Ki for lithium of its major hypothesized targets $(\geq 1 \mathrm{mM})$. Indeed, in the antidepressantlike rodent model, the forced-swim test, only plasma lithium levels above $1.3 \mathrm{meq} / \mathrm{L}$ significantly reduced immobility-time (Bersudsky et al., 2007). Importantly, it has recently been shown (Yáñez et al., 2014) that lithium-induced neuroprotection is antagonized by riluzole (the only FDAapproved drug for ALS), suggesting that the drug's neurotoxic effects may mask the potential neuroprotective activity of lithium.

In conclusion, we believe that the potential beneficial effect of lithium for neurodegenerative disorders deserves serious reconsideration.

\section{REFERENCES}

Bersudsky, Y., Shaldubina, A., and Belmaker, R. H. (2007). Lithium's effect in forced-swim test is blood level dependent but not dependent on weight loss. Behav. Pharmacol. 18, 77-80. doi: 10.1097/FBP.0b013e32801416ed

Fornai, F., Longone, P., Cafaro, L., Kastsiuchenka, O., Ferrucci, M., Manca, M. L., et al. (2008). Lithium delays progression of amyotrophic lateral sclerosis. Proc. Natl. Acad. Sci. U.S.A. 105, 2052-2057. doi: 10.1073/pnas.0708022105. Erratum in: Proc. Natl. Acad. Sci. U.S.A. 105, 16404-16407.

Gill, A., Kidd, J., Vieira, F., Thompson, K., and Perrin, S. (2009). No benefit from chronic lithium dosing in a sibling-matched, gender balanced, investigator-blinded trial using a standard mouse model of familial ALS. PLoS ONE 4:e6489. doi: 10.1371/journal.pone.00 06489
Perrin, S. (2014). Make mouse studies work. Nature 507, 423-425. doi: 10.1038/507423a

Sade, Y., Kara, N. Z., Toker, L., Bersudsky, Y., Einat, H., and Agam, G. (2014). Beware of your mouse strain; differential effects of lithium on behavioral and neurochemical phenotypes in Harlan ICR mice bred in Israel or the USA. Pharmacol. Biochem. Behav. 124C, 36-39. doi: 10.1016/j.pbb.2014.05.007

UKMND-LiCALS Study Group, Morrison, K. E., Dhariwal, S., Hornabrook, R., Savage, L., Burn, D. J., et al. (2013). Lithium in patients with amyotrophic lateral sclerosis (LiCALS): a phase 3 multicentre, randomised, doubleblind, placebo-controlled trial. Lancet Neurol. 12, 339-345. doi: 10.1016/S1474-4422(13)7 0037-1.

Yáñez, M., Matías-Guiu, J., Arranz-Tagarro, J. A., Galán, L., Viña, D., Gómez-Pinedo, U., et al. (2014). The neuroprotection exerted by memantine, minocycline and lithium, against neurotoxicity of CSF from patients with amyotrophic lateral sclerosis, is antagonized by riluzole. Neurodegener. Dis. 13, 171-179. doi: $10.1159 / 000357281$

Conflict of Interest Statement: The authors declare that the research was conducted in the absence of any commercial or financial relationships that could be construed as a potential conflict of interest.

Received: 01 July 2014; accepted: 08 August 2014; published online: 02 September 2014.

Citation: Agam G and Israelson A (2014) Why lithium studies for ALS treatment should not be halted prematurely. Front. Neurosci. 8:267. doi: 10.3389/fnins. 2014.00267

This article was submitted to Neuropharmacology, a section of the journal Frontiers in Neuroscience.

Copyright (c) 2014 Agam and Israelson. This is an open-access article distributed under the terms of the Creative Commons Attribution License (CC BY). The use, distribution or reproduction in other forums is permitted, provided the original author(s) or licensor are credited and that the original publication in this journal is cited, in accordance with accepted academic practice. No use, distribution or reproduction is permitted which does not comply with these terms. 